\title{
Hepatit B Virus Enfeksiyonu ve Glutatyon
}

\section{Glutathione and Chronic Hepatitis B Virus Infection}

Arzu Șenol

${ }^{1}$ Sağlık Bilimleri Üniversitesi, Fethi Sekin Şehir Hastanesi, Enfeksyon Hastalıkları ve Klinik Mikrobiyoloji

\section{$\ddot{O} z$}

Amaç: Bu çalışmada, hepatit B virus enfeksiyonlu olgularda, karaciğer enflamasyonunu, hastalık progresyonunu takip etmede ve karaciğer hasarının ilerleyip, kronik karaciğer hastalığı ve komplikasyonların oluşmasını önlemede tedavi için kullanılabilecek antioksidan glutatyonun serum düzeylerine bakıldı.

Gereç ve Yöntem: Çalışmaya hepatit B virus enfeksiyonlu, ALT düzeyleri normal, HBV DNA Neg- $<104 \mathrm{c} / \mathrm{ml}$, 18-69 yaş arası 55 olgu ile sağlıklı, herhangi bir kronik hastalığı ve akut hepatit olmayan 40 kontrol grubu alındı. Serum GSH düzeyleri, ELISA (Enzyme-Linked Immunosorbent Assay) yöntemi (R\&D Systems, Minneapolis, MN, USA) ile belirlendi.

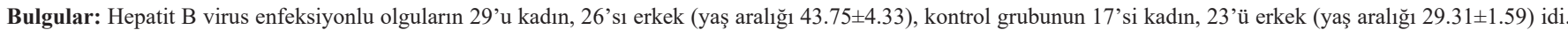
hepatit B virüs enfeksiyonlu olgular arasında serum GSH düzeyi ile yaş ve cinsiyet arasında istatistiksel olarak anlamlı bir farklılık saptanmadı (sırasıyla p: 0.252, p: 0.353). Hepatit B virus enfeksiyonunda glutatyon serum düzeyleri kontrol grubundan düşük olup bu istatiksel açıdan anlamlıydı (sırasyla $117.47 \pm 3.12,151.18 \pm 1.93$ ng/ $\mathrm{mL}, \mathrm{p}: 0.001$ ). Hepatit B enfeksiyonunda, biyokimyasal parametreler ve glutatyon arasında istatiksel olarak anlamlı bir fark saptanmadı ( $\mathrm{p}>0.05$ ).

Sonuç: Oksidatif stres, karaciğer hasarının gelişimi ve ilerlemesinde önemlidir. Glutatyon, hepatit B enfeksiyonlu olgularda, karaciğer enflamasyonunu, hastalık progresyonunu takip etmede kullanılabilir. Ayrıca, antioksidan etkisiyle enflamasyonu baskılayarak, kronik karaciğer hastalığı ve komplikasyonların oluşumunu önlemek için tedavide kullanılabilir.

Anahtar kelimeler: Hepatit B virus enfeksiyonu, glutatyon, oksidatif stres

Abstract

Objective: In this study, serum levels of antioxidant glutathione which can be used to follow of liver inflammation and disease progression and in treatment to prevent progressive liver damage and chronic liver disease and complications in patients with hepatitis B virus infection, were evaluated.

Material and Methods: The study included 55 patients with hepatitis B virus infection, normal ALT levels, HBV DNA Neg- $<104 \mathrm{c} / \mathrm{ml}$, between the ages of $18-69$ and 40 healthy controls, without any chronic disease or acute hepatitis. Serum GSH levels were determined by ELISA (Enzyme-Linked Immunosorbent Assay) method (R\&D Systems, Minneapolis, MN, USA)

Results: Of the hepatitis B virus infected cases, 29 were female and 26 were male (age range $43.75 \pm 4.33$ ), 17 of the control group were female and 23 were male (age range $29.31 \pm 1.59$ ). No statistically significant difference was found between the serum GSH level and age and gender among the cases with hepatitis B virus infection (p: 0.252 , p: 0.353 , respectively). Glutathione serum levels in hepatitis B virus infection were lower than control group and this was statistically significant (117.47 \pm 3.12 , $151.18 \pm 1.93 \mathrm{ng} / \mathrm{mL}$, respectively, p:0.001). There was no statistically significant difference between biochemical parameters and glutathione in patients with hepatitis B virus infection $(\mathrm{p}>0.05)$.

Conculusion: Oxidative stress is important in the development and progression of liver damage Glutathione can be used in patients with hepatitis B infection, to follow liver inflammation and disease progression. In addition, it can be used in treatment to prevent the occurrence of chronic liver disease and complications by suppressing inflammation with its antioxidant effect.

Keywords: Hepatitis B virus infection, glutathione, oxidative stress

Yazışma Adresi: Arzu Şenol, Fethi Sekin Şehir Hastanesi, Enfeksiyon Hastalıkları ve Klinik Mikrobiyoloji Departmanı, Ulukent

Mahallesi (Doğukent Depo Mevkii) Onbaşı Sokak No: 99, 23100, Elazı̆̆

E-Posta: asenol2017@gmail.com

Alınma tarihi: 22.07.2020 / Kabul tarihi: 15.12.2020 / Yayımlanma tarihi: 20.09.2021

Hepatit B'de Glutatyonun Rolü - Şenol.

Genel Tip Derg 2021;31(3)239-242 
Hepatit B virus enfeksiyonu (HBE), dünyada önemli ve yaygın global problemlerden biridir. Dünyada hepatit B virüsü (HBV), yaklaşık 400 milyon insanda hepatitin ana nedenidir ve yılda 200.000500.000 ölüme neden olmaktadır (1). Türkiye'de 2010 yılında 2.060.000 Hepatit B surface antijen (HBsAg) pozitif yetişkin olduğu, kronik hepatit ve karaciğer sirozlarının (KS) yaklaşı \% $40-45$ 'inden HBV‘nin sorumlu olduğu saptanmıştır. Erişkin nüfusun yaklaşık 1/3'ü HBV ile karşılaşmıştır (2).

Hepatit B virus enfeksiyonu; immün toleran faz, inaktif $\mathrm{HBsAg}$ taşıyıcı faz ve çözülmüş hepatit B fazından oluşur. Bu olgularda KS, hepatosellüler kanser (HSK) gelişme riski olmasına rağmen; çoğunda, bu hepatik komplikasyonlar gelişmeyebilir ve olguların yaklaşık \%60-80'inde ALT seviyeleri normaldir (3). Hepatit B virusunun yüksek replikasyon oranı sürekli enflamasyona ve artan fibrozise neden olur $(4,5)$.

Bazı durumlarda oksidan seviyesi yükselir ve antioksidanlar yetersiz kalır. Bu denge bozulursa oksidan moleküller organizmanın yapı taş1 olan protein, lipid, karbonhidrat, nükleik asitler ve enzimlerin yapısını bozarak zararlı etkilere yol açarlar. Bu durum oksiidatif stres (OS) olarak adlandırılır (6). Oksidatif stres, HBE'de karaciğer hasarında önemli bir patojenik rol oynar (7).

Glutatyon ( $\gamma$-glutamil-sisteinil-glisin) (GSH), her tür hücrede sentezlenebilen ve özellikle karaciğerde bulunan en önemli antioksidanlardan biridir. Ayrıca, bir redoks ve hücre sinyal regülatörüdür. Hidrojen peroksit seviyesini düşürür, reaktif oksijen ve azot radikallerini, toksik bileşikleri temizler(8). Enzimatik olmayan antioksidan olan GSH, OS'e karşı ana hücre içi savunma mekanizmasıdır. Glutatyonun interlökin 6 (IL-6), IL-8 ve tümör nekroz faktör (TNF)- $\alpha$ sentezini inhibe ederek karaciğer hücrelerinde sitokin kaynaklı hasarı azaltabileceği bildirilmiştir (9). Tedavide kullanılan ilaçların iyileştirici etkisinin yanında antioksidan etkilerinin de olması tedavi şansını artırmakta ve oksidatif hasara bağlı hastalık oluşumunu kısmen önlemektedir (10).

Vücut doğal yoldan glutatyon üretmekte ama bu yaşla birlikte azalmaktadır. 20 yaşından sonra doğal glutatyon üretimi her on yılda ortalama \%10 azalmaktadır. Glutatyon, yaşlanma, kanser, kalp damar hastalıkları ve başka birçok kronik/dejeneratif hastalığın önlenmesinde temel öneme sahiptir (11).

Bu çalışmada, HBE'li olgularda karaciğer enflamasyonunu, hastalık progresyonunu takip etmede tanı amaçlı, ayrıca, karaciğer hasarının ilerleyip kronik karaciğer hastalığı ve komplikasyonların oluşmasını önlemede tedavi amaçlı kullanılabilecek antioksidan GSH'ın serum düzeylerini belirlemek amaçlandı.

\section{Gereç ve Yöntem}

Helsinki Deklarasyon ilkelerine uygun olarak gerçekleştirilen bu çalışma Fırat Üniversitesi Kurumsal Değerlendirme Kurulu tarafından 18.01.2018 tarih ve 07 sayılı kararla onaylanmış prospektif bir çalışmadır. Klinik bilgi ve kan örneklerinin toplanmasından önce çalışma ile ilgili katılımcılar bilgilendirilmiş ve çalışma için yazılı onay alınmıştır.

Hastalar ve kontroller: Bu çalışmaya 2018 yılı ocak-ekim ayları arasında enfeksiyon hastalıkları polikliniğine başvuran, 6 aydır
HBsAg pozitif, HBeAg negatif, serum alanin aminotransferaz (ALT) düzeyleri normal, HBV viral yük (HBV DNA) Neg-<104 c/ml, 1869 yaş aralığında $55 \mathrm{HBeAg-negatif} \mathrm{HBE} \mathrm{(eski} \mathrm{terminoloji:} \mathrm{inaktif}$ taşıyıc1) hastası dahil edildi. HBeAg-negatif HBE tanısı European Association for the study of the liver (EASL) kriterlerine göre konuldu (12). Aynı zamanda herhangi bir komorbiditesi ve karaciğer hastalık öyküsü olmayan, yaş ve cinsiyeti eşleştirilmiş, 40 kişiden oluşan sağlıklı kontrol grubu oluşturuldu. Hepatit A, Hepatit C ve human immundeficieny virüs koenfeksiyonu olan, hepatoselüler karsinom/sirozu olan, 18 yaş altı, sistemik hastalığı ya da otoimmün seroloji pozitifliği olan hastalar ise çalışma dışı bırakıldı.

Hastaların rutin analizlerin bir parçası olarak hepatit B surface antijeni (HBsAg), hepatit B early antijeni ( $\mathrm{HBeAg}$ ), hepatit B early antikoru (antiHBe), HBV viral yük (HBVDNA), serum alanin aminotransfeaz (ALT) ve aspartat aminotransferaz (AST), gama glutamil transferaz (GGT), Alfa-fetoprotein (AFP), platelet düzeylerini içeren standart kan analizleri yapıld1.

Serum GSH düzeylerinin belirlenmesi: Hastalardan periferik venöz kandan yaklaşık 5 cc kan alındı ve EDTA içeren tüplere ayrıldı. Toplandıktan sonra 30-40 dakika içinde, elde edilen kan örnekleri $3500 \mathrm{rpm}$ 'de 10 dakika santrifüj edildi. Serumlar $-80^{\circ} \mathrm{C}$ derecede derin dondurucuda saklandı. Serumlar çalışma günü oda sıcaklığına getirilip eritildi. Serum GSH düzeyleri, ELISA (Enzyme-Linked Immunosorbent Assay) yöntemi (R\&D Systems, Minneapolis, MN, USA) ile belirlendi. Test sonuçları ng/mL (ELISA kit saptama aralığ $1.25-80 \mathrm{ng} / \mathrm{mL}$ ) olarak ifade edildi. Çalışma için herhangi bir finansal destek alınmadı.

\section{İstatistiksel değerlendirme}

Veri analiz işlemleri SPSS 22.0 (Chicago, ABD) paket istatistik programı kullanılarak gerçekleştirildi. Sürekli değişkenlerin normal dağılıma uygunluğunu belirlemek için Kolmogorov-Smirnow ve Shapiro-Wilk normallik analizi yapıldı. Normal dağılıma uyan sürekli değişkenlerin analizinde Student $\mathrm{t}$ testleri kullanıldı. Kategorik verilerin analizinde " pearson ki-kare testi" kullanıldı. Ortalama \pm standart ve $\%$ veriler saptandi. İstatistiksel verilerin karşılaştırılmasında $\mathrm{P}<0.05$ değeri anlamlı olarak kabul edildi.

\section{Bulgular}

Hepatit B virus enfeksiyonlu olguların 29'u kadın, 26'i erkek (yaş aralığı 43.75 \pm 4.33 ), kontrol grubunun 17'si kadın, 23'ü erkek (yaş aralığı 29.31 \pm 1.59 ) idi. Hepatit B enfeksiyonlu olguların yaş ortalaması, kontrol grubundan daha yüksekti. Ancak HBE'lu olgularında, serum GSH düzeyi ile yaş ve cinsiyet arasında istatistiksel olarak anlamlı bir farklılı saptanmadı (sırasıly p: 0.252 , p: 0.353).

Hepatit B virus enfeksiyonunda, GSH serum düzeyleri kontrol grubundan düşük olup bu istatiksel açıdan anlamlıydı (sırasıyla $117.47 \pm 3.12, \quad 151.18 \pm 1.93 \mathrm{ng} / \mathrm{mL}, \mathrm{p}: 0.001$. Hepatit B virus enfeksiyonu olgularında ALT, AST, GGT ve AFP ile GSH serum düzeyleri arasında istatistiksel olarak anlamlı bir farklılık saptanmadı (sirasiyla p: 0.251, p: 0.251, p: 0.265, p: 0.242). Hepatit B virus enfeksiyonu ve kontrol grubunun demografik özellikleri, laboratuvar testlerinin ortalama değerleri, serum GSH düzeyleri ve $\mathrm{p}$ değerleri tablo 1' de özetlenmiştir.

Hepatit B'de Glutatyonun Rolü - Şenol. 
Tablo 1. Hepatit B virus enfeksiyonu olgularının ve kontrol grubunun demografik özellikleri, laboratuvar testlerinin ortalama değerleri, serum glutatyon düzeyleri

\begin{tabular}{|l|c|c|c|}
\hline & $\begin{array}{c}\text { Hepatit B virus } \\
\text { enfeksiyonu }\end{array}$ & Kontrol & p değeri \\
\hline Yaş & $43.75 \pm 4.33$ & $29.31 \pm 1.59$ & 0.004 \\
\hline Cinsiyet(K/E) & $29 / 26$ & $17 / 23$ & 0.580 \\
\hline AST(IU/L) & $20.728 \pm 2,45$ & $17.45 \pm 1,03$ & 0.234 \\
\hline ALT(IU/L) & $24.45 \pm 3.98$ & $19.73 \pm 1.19$ & 0.318 \\
\hline GGT(IU/L) & $18.55 \pm 1.88$ & $18.27 \pm 1.76$ & 0.917 \\
\hline AFP( $\mu$ g/L) & $1.99 \pm 1.86$ & $1.93 \pm 1.66$ & 0.617 \\
\hline T. Billurubin & $0.39 \pm 0.06$ & $0.38 \pm 0.05$ & 0.971 \\
\hline PTZ & $11.56 \pm 0.35$ & $11.52 \pm 0.34$ & 0.730 \\
\hline Platelet(10^3/L) & $270 \pm 147$ & $218 \pm 109$ & 0.091 \\
\hline GSH & $117.47 \pm 3.12$ & $151.18 \pm 1.93$ & 0.001 \\
\hline
\end{tabular}

AST:Aspartat Aminotransferaz; ALT:Alanin Aminotransferaz; GGT: Gama glutamil transferaz; AFP: Alfa feto protein; PTZ: Protrombin zamanı; K: Kadın; E: Erkek; Glutatyon: GSH

\section{Tartışma}

Dünya nüfusunun büyük bir bölümü $\mathrm{HBV}$ ile yaşamlarının herhangi bir evresinde karşılaşmıştır. Hepatit B virüsü ile ilişkili karaciğer hasarı yıllar içerisinde karaciğer fibrozisine ilerler (13). $\mathrm{Bu}$ progresyon, aktif karaciğer enflamasyonu ve hasar derecesine bağlı olarak hızlı veya yavaş olabilir. Ancak bu durumun başlıca belirleyicisi hastalığın başlangıç evresidir (14). Bu nedenle, inaktif taşıyıcıların yakın takibi önemlidir (15). Bu çalışmada, HBeAgnegatif HBE hastalarında GSH'ın serum düzeylerini saptamak ve tanısal değerini ortaya koymak amaçlanmıştır.

Toplumda yaşlı grubun temsili bir çalışmasında, daha yüksek GSH seviyeleri daha az hastalık ile ilişkilendirilmiştir. Bir çalışmada, 6079 yaş grubundaki GSH seviyeleri kontrol grubundan \%17 daha düşük bulunmuştur. Glutatyon serum örneklerinin analizi, yaşlanma ve diğer hastalıklarda azalmış GSH rolünün anlaşılmasında önemlidir (16). Bu çalışmada, HBE'li olguların serum GSH düzeyi kontrol grubundan düşüktü, yaş ortalaması ise kontrol grubundan yüksekti. $\mathrm{Bu}$ da yaş ortalaması arttıkça GSH düzeyinin azaldığını gösterebilir. Ancak HBE'li olgularda GSH düzeyi ile yaş arasında istatistiksel olarak anlamlı bir farklılık gözlenmedi ( $\mathrm{p}>0.05)$.

Östrojenin antioksidan özelliği bulunmaktadır. DNA'da OS hasarını gösteren 8-oksideoksiguanozin miktarı erkeklerde kadınlardan dört kat yüksek bulunmuştur. Ayrıca, hücre içi antioksidan olan GSH'ın mitokondriyal miktarının erkeklerde kadınlarınkinin yarısı kadar olduğu bildirilmektedir $(17,18)$. Bu çalışmada ise HBE'li olgularda, serum GSH düzeyleri ile kadın ve erkek cinsiyet arasında anlamlı bir farklılık saptanmadı (sırasiyla p: 0.252, p: 0.353).

Hepatit B virus enfeksiyonları sırasında oluşan karaciğer hasarının kronikleşmesinin mekanizması tam olarak açıklanmamıştır. Oksidatif stresin viral hepatitin ilerlemesine ve karaciğer hasarının artmasına katkıda bulunduğu öne sürülmüştür (19). Hepatit B ile enfekte bireylerde, enflamasyon seviyelerinin saptanmas1 hastaların takibi yönünden önemlidir. Enflamasyon ve kronikleşme seviyesini saptamak için invaziv olmayan metodların yapılması önem arz etmektedir (15). Bu nedenle, HBE'li olguların klinik değerlendirmesinde OS göstergelerinin ölçümünün $\mathrm{HBV}$ belirteçleriyle birlikte kullanılabileceği ileri sürülmüştür (20). Ciddi kronik hepatit $\mathrm{B}(\mathrm{KHB})$ olgularında, HBV replikasyonu sırasında lipid peroksidasyonunun arttığ ve total antioksidan kapasitenin azaldığ1 gösterilmiştir (21). Artmış lipid peroksidasyonu, viral enfeksiyona bağlı enflamasyon ve azalmış antioksidan seviyelerinden kaynaklanabilir(22).

Akut veya kronik viral hepatit hastalarında eritrosit GSH konsantrasyonunun önemli ölçüde azaldığı gösterilmiştir. Bir çalışma, hem viral hem de diğer etiyolojiye sahip kronik karaciğer hastalığı olan olgularda, GSH konsantrasyonunun sağlıklı kontrollere göre anlamlı derecede düşük olduğunu bildirmiştir. Antioksidan seviyelerindeki bu düşüklüğün ROS üretimini kolaylaştırabileceğini bunun da kronik karaciğer hastalıklarının patogenezinde rol oynayabileceğini belirtmiştir (23). Lin ve ark. (19)'nın yaptığı bir çalışmada, KHB'li olgularda, sağlıklı kontrollere göre daha düşük GSH düzeyi görülmüştür. Nitekim bizim çalışmamızda bu verileri destekler nitelikte sonuçlanmış olup, HBE'li olgularda, GSH düzeyi kontrol grubuna göre düşük saptanmıştır. Bu durum, bu olgularda antioksidan etkinin azaldığını düşündürebilir.

Gama-glutamil transferaz, hücre içi indirgenmiş GSH sentezi için gerekli öncül amino asitlerin sağlanmasında görev alan bir enzimdir. Bu şekilde, GGT'nin antioksidan etki gösterdiği bildirilmiştir (24). GGT artış1, birçok karaciğer hastalığında görülmektedir(25). Bu çalışmada ise, HBE'li olgularda, GGT düzeyi ile GSH arasında istatistiksel olarak anlamlı bir ilişki gözlenmedi (p: 0.265).

Karaciğer enzimleri ALT ve AST, karaciğer fonksiyon değerlendirmesi için en yaygın olarak kullanılan serum biyobelirteçleridir. Hepatosellüler hasarı göstermede, AST ve ALT seviyelerini değerlendiren bir çalışmada, serum AST, ALT değerinin şiddetli hepatitte, güvenilir bir gösterge olmadığı öne sürülmüştür. Bir çalışmada, değişken derecelerde karaciğer hasarı olan 263 KHB hastasında serum ALT, AST sağlıklı kontrollere göre istatistiksel olarak anlamlı derecede yüksek olduğu saptanmıştır (26). Bu çalışmada, HBE'li olgularda AST, ALT değerleri normal sınırlardaydı (5-50 IU/ML) ve AST, ALT düzeyi ile GSH arasında anlamlı bir farklılık yoktu (p: 0.251).

Bununla birlikte, çalışmanın bazı sınırlılıkları vardır. Çalışmada nispeten küçük bir örneklem büyüklüğünün olması ve KHB olgularının bulunmaması, bulgularımızın çok merkezli, daha büyük bir kohortta doğrulanmasını gerektirmektedir.

Sonuç olarak, OS, karaciğer hasarının patogenezinde ve ilerlemesinde önemli bir rol oynamaktadır. Özellikle, HBE’nin progresyonunda oksidan ve antioksidan sistem arasındaki denge önemlidir. Bu çalışmada, HBE'li olgularda serum GSH düzeyi, kontrol grubundan istatistiksel olarak anlamlı düşük bulundu. Bu da GSH'ın, patogenezde etkili olabileceğini ve diğer OS göstergeleri ile birlikte karaciğer enflamasyonu ve hasarının progresyonunu göstermede bir marker olarak kullanılabileceğini gösterebilir. Ayrıca, antioksidan tedavinin viral yükü azalttı̆̆1 ve hepatik hasarı iyileştirdiği bildirilmiştir (27). Bu amaçla bir antioksidan olan GSH'nın ekzojen uygulanması, antioksidatif etkiyi artırabilir, sitokin kaynaklı hasarı azaltabilir. Böylece, karaciğer fonksiyonlarının kısa sürede düzelmesi sağlanarak, progresyonun önlenmesi mümkün olabilir. Tüm bu veriler 1şı̆̆ında, HBE olguların, serum GSH düzeyinin çalışılması için ideal bir popülasyon olduğu söylenebilir. 
Teşekkür: Serum glutatyon düzeyini tayin konusunda yöntem ve teknik açıdan destek veren Doç. Dr. Zafer Çambay’a katkılarından dolayı teşekkür ederim.

\section{Kaynaklar}

1. Taşbakan MI, Sertöz ÖÖ, Pullukçu H, et al. Comparison of quality of life in hepatitis B virus carriers versus chronic hepatitis B virus carriers versus the normal population. Turk J Med Sci 2010; 40 (4): 575-583.

2. Aygen B, Demir AM, Gümüș M, et al. Immunosuppressive therapy and the risk of hepatitis B reactvation. Consensus report. Turk J Gastroenterol 2018; 29:259-69.

3. Conde SRS, Feitosa RNM, Freitas FB, et al. Association of cytokine gene polymorphisms and serum concentrations with the outcome of chronic hepatitis B. Cytokin 2013; 61:940-944.

4. McMahon BJ. Chronic hepatitis B virus infection. Med Clin North Am 2014; 98:3954.

5. Besharat S, Poustchi H, Mohamadkhani A, et al. Association of Mutationsin the Basal Core Promoter and Pre-core Regions ofthe Hepatitis B Viral Genome and Longitudinal Changesin HBV Level in HBeAg Negative Individuals: Results From a Cohort Study in Northern Iran. Hepat Mon 2015; 15:23875.

6. Valko M, Leibfritz D, Moncol J, et al. Free radicals and antioxidants in normal physiological functions and human disease. The International Journal of Biochemistry \& Cell Biology 2007; 39: 44-84.

7. Moossavi S, Besharat S, Sharafkhah M, et al. Inverse Association of Plasma Level of Glutathione Peroxidase with Liver Fibrosis in Chronic Hepatitis B: Potential Role of Iron. Middle East Journal of Digestive Diseases 2016; 8(2): 122-130.

8. Paracha UZ, Fatima K, Alqahtani M, et al. Oxidative stress and hepatitis C virüs. Virology Journal 2013; 10: 251

9. Qian L, Wang W, Zhou Y, Ma J. Effects of reduced glutathione therapyon chronic hepatitis B. Cent Eur J Immunol 2017; 42 (1): 97-100.

10. Dragonjic LP, Jovanovic M, Cvetkovic T, et al. Erythrocyte antioxidative enzymes activities in patients with chronic hepatitis $\mathrm{C}$ treated with pegylated interferon alpha-2a and ribavirin. Vojnosanit Pregl 2017; 74(9): 840-848.

11. Jones DP, Coates RJ, Flagg EW, et al. Glutathione in foods listed in the National Cancer Institute's Health Habits and History Food Frequency Questionnaire. Nutrition and Cancer 1992; 17(1): 57-75.

12. European Association for the study of the liver (EASL) 2017 Clinical Practice Guidelines on the management of hepatitis B virus infection. http://www.easl.eu/ medias/cpg/management-of-hepatitis-B-virus-infection/English-report.pdf (accepted date:12.02.2018)

13. Yilmaz B, Aydin H, Can G, et al. The relationship between fibrosis level and blood neutrophil to lymphocyte ratio in inactive hepatitis B carriers. European Journal of Gastroenterology \& Hepatology 2014; 26: 1325-28.

14. Crossan $\mathrm{C}$, Tsochatzis EA, Longworth $\mathrm{L}$, et al. Costeffectiveness of non-invasive methods for assessment and monitoring of liver firosis and cirrhosis in patients with chronic liver disease: systematic review and economic evaluation. Health Technol Assess 2015; 19: 1-409.

15. Guo GH, Tan DM, Zhu PA, et al. Hepatitis B virus $X$ protein promotes proliferation and upregulates TGFbeta1 and CTGF in human hepatic stellate cell line, LX-2. Hepatobiliary Pancreat Dis Int 2009; 8: 59-64.

16. Singh RJ. Glutathione: A marker and antioxidant for aging. J Lab Clin Med 2002; 140(6):380-1.

17. Pan Z, and Chang C. Gender and the regulation of longevity: Implications for autoimmunity. Autoimmunity Reviews 2012; 11: 393-403.

18. Regan JC, and Partridge L. Gender and Longevity: Why do men die earlier than women? Comparative and experimental evidence. Best Practice and Research Clinical Endocrinology and Metabolism 2013; 27: 476- 479.

19. Lin C, Liu W, Wang Z, et al. Vitamins B status and antioxidative defense in patients with chronic hepatitis B or hepatitis C virus infection. Eur J Nutr 2011; 50: 499-506.

20. Kaya S, Sütçü R, Çetin ES, ve ark. Hepatit B Virusü ile İnfekte Hastalarda Viral Yük ile Lipid Peroksidasyonu ve Antioksidan Enzimler Arasındaki İlișki. Türk Klinik Biyokimya Dergisi 2006; 4(2):77-82
21. Sırmatel F, Duygu F, Çelik H, ve ark. Kronik Viral Hepatit Olgularında Total Oksidatif Seviye ve Total Antioksidan Kapasitenin Değerlendirilmesi. Klimik Dergisi 2009; 22(3): 92-6.

22. Ismail NA, Okasha SH, Dhawan A, et al. Glutathione peroxidase, superoxide dismutase and catalase activities in children with chronic hepatitis Advances in Bioscience and Biotechnology 2012; 3: 972-97.

23. Czuczejko J, Zachara BA, Topczewska ES, et al. Selenium, glutathione and glutathione peroxidases in blood of patients with chronic liver diseases. Acta Biochimica Polonica 2003; 50(4): 1147-1154.

24. Şener A, Çevik Ö. Gama-glutamil transferazın oksidatif stres ve kardiyovasküler hastalıklarla ilişkisi. Cumhuriyet Tıp Derg 2013; 35: 291-301.

25. Aygün C, Gözel N, Demirel U, ve ark. Kronik Viral Hepatit B Tanısı Olan Hastalarda Serum GGT Düzeyi İle Karaciğer Fibrozu İlişkisi. Fırat Tıp Dergisi 2010; 15(2): 74-78.

26. Karlıdağ GE, Ertürk ÜȘ. Kronik Hepatit B Hastalarında Karaciğer Histolojisini Öngörmede Noninvaziv Biyokimyasal Belirteçlerin Değerlendirilmesi. F.Ü. Sağ. Bil. Tip. Derg 2020; 34 (1): 01-06.

27. Amatore $\mathrm{D}$, Matarrese $\mathrm{P}$, Angelis MD, et al. Counteraction of HCV-Induced Oxidative Stress Concurs to Establish Chronic Infection in Liver Cell Cultures. Oxidative Medicine and Cellular Longevity 2019; 10: 1-14. 